\title{
The activity patterns and microhabitat use of Pseudis minuta Günther, 1858 (Anura, Hylidae) in the Lagoa do Peixe National Park, a biosphere reserve of the brazilian subtropics
}

\author{
Huckembeck, S. $^{a *}$, Claudino, M. ${ }^{a}$, Correa, F. ${ }^{a}$, Bastos, RF. ${ }^{a}$, \\ Loebmann, D. ${ }^{b}$, Tozetti, AM. ${ }^{b}$ and Garcia, AM. ${ }^{b}$ \\ aLababoratório de Ictiologia, Instituto de Oceanografia, Universidade Federal do Rio Grande - FURG, \\ Av. Itália, Km 8, CEP 96201-900, Rio Grande, RS, Brazil \\ ${ }^{b}$ Lababoratório de Vertebrados Terrestres, Programa de Pós-graduação em Biologia de Ambientes Aquáticos Continentais, \\ Instituto de Ciências Biológicas, Universidade Federal do Rio Grande - FURG, \\ Av. Itália, Km 8, CEP 96201-900, Rio Grande, RS, Brazil \\ *e-mail: sohuckembeck@yahoo.com.br
}

Received July 6, 2011 - Accepted February 8, 2011 - Distributed May 31, 2012

(With 2 figures)

\begin{abstract}
Pseudis minuta is abundant in a variety of aquatic environments of the Pampa domain. Therefore, it can be considered a good model for testing hypotheses on environmental heterogeneity and the influence of climate on the activity of anurans. In this study, we examined the spatial distribution pattern of $P$. minuta in terms of microhabitats and the influence of abiotic factors on seasonal fluctuations in the abundance of this species. Samples were collected monthly from April 2008 to May 2009 in wetlands and coastal dunes in the Lagoa do Peixe National Park. A total of 112 specimens of P. minuta were collected, of which 45 were found in the wetland area and 67 in the dune area. The species showed seasonal fluctuation in abundance, and it was most abundant in months with higher temperatures (spring-summer). Pseudis minuta was mainly associated with aquatic vegetation, an expected pattern in terms of their morphological adaptations to this environment. Among the abiotic parameters analyzed, only the monthly mean temperature showed a significant correlation ( $\mathrm{p}<0.05 ; \mathrm{r}=0.67$ ) with the abundance of $P$. minuta. We concluded that $P$. minuta is a generalist species with respect to microhabitat use and also that fluctuation in its population abundance is mainly associated with seasonal variation in temperature.
\end{abstract}

Keywords: abundance, anuran, coastal plain, Lagoa do Peixe, spatiotemporal distribution.

\section{Padrão de atividade e uso de micro-habitat de Pseudis minuta Günther, 1858 (Anura, Hylidae) no Parque Nacional da Lagoa do Peixe, uma reserva da biosfera na região subtropical do Brasil}

\begin{abstract}
Resumo
Pseudis minuta é uma espécie abundante em diferentes tipos de ambientes aquáticos do domínio Pampa. Por essa razão, essa espécie pode ser considerada um bom modelo para testar hipóteses relacionadas à heterogeneidade ambiental e à influência do clima sobre padrões de atividade em anuros. Neste trabalho, foi avaliado o padrão de distribuição espacial de P. minuta em termos de micro-habitats, além de se avaliar a influência de fatores abióticos nas flutuações sazonais da abundância dessa espécie. Coletas foram realizadas mensalmente, entre abril de 2008 e maio de 2009 , em áreas úmidas e de cordões de dunas costeiras no Parque Nacional de Lagoa do Peixe. Um total de 112 indivíduos de P. minuta foi coletado, sendo 45 em áreas de banhado e 67 em área de dunas. A espécie apresentou flutuação sazonal na abundância, sendo mais abundantes em meses com temperaturas mais elevadas (primavera-verão). Pseudis minuta esteve associada principalmente à vegetação aquática, um padrão esperado em função de suas adaptações morfológicas a esse meio. Entre os parâmetros abióticos analisados, somente a temperatura média mensal apresentou correlação significativa ( $\mathrm{p}<0.05 ; \mathrm{r}=0,67)$ com a abundância de $P$. minuta. Foi possível concluir que $P$. minuta é uma espécie generalista com relação ao uso do habitat e que as flutuações na sua abundância populacional estão principalmente associadas à variação sazonal da temperatura.
\end{abstract}

Palavras-chave: abundância, anuro, planície costeira, Lagoa do Peixe, distribuição espaço-temporal. 


\section{Introduction}

Weather conditions and habitat heterogeneity play a major role in the reproductive activities and distribution patterns of amphibians (Vasconcelos and Rossa-Feres, 2005, 2008). Previous studies have shown that temperature is the main factor influencing anuran activities in temperate regions, whereas rainfall is a primary factor triggering reproduction at subtropical and tropical latitudes (Duellman and Trueb, 1994). Moreover, other abiotic factors, such as relative humidity, atmospheric pressure and light intensity, can also influence the reproductive activity of amphibians (e.g., Wiest Junior, 1982; Aichinger, 1987).

In contrast, habitat heterogeneity can influence the distribution patterns of anurans. It provides distinct microhabitats for vocalization (Vasconcelos and Rossa-Feres, 2008), refuge from predators (Tozetti and Toledo, 2005) and an array of different food resources (Brandão et al., 2003). Patterns of habitat use by anurans can vary widely. Some generalist species occur in a variety of habitats from open areas to the interior of forests (Conte and Rossa-Feres, 2007), whereas other site-specific species are restricted to microhabitats, such as bromeliads (Schineider and Teixeira, 2001).

Increasing numbers of herpetological studies have been conducted in the Neotropics. However, most of these studies were conducted in tropical areas. These areas are particularly influenced by the wet-warm and dry-cold periods that characterize the climate (Duellman, 1995). Few herpetological studies have been performed in areas with a subtropical climate, particularly in southern South America. It is plausible that the lower air temperatures and distinct annual rainfall regime found in the subtropical region could produce an activity pattern for anurans distinct from that found in the tropics. In addition, the predominance of open habitats (e.g., grasslands) associated with the temporary ponds very often found in southern Brazil would encourage habitat generalist species. In view of these hypotheses, we investigated the patterns of activity and microhabitat use of Pseudis minuta Günther, 1858 in the "Lagoa do Peixe" National Park, a poorly investigated UNESCO Biosphere Reserve in a subtropical region $\left(31^{\circ} \mathrm{S}\right)$ of southern Brazil. Pseudis minuta is commonly found in the coastal plain of this region, especially in temporary or permanent ponds, particularly those with aquatic vegetation (Achaval and Olmos, 2003). Although the species' reproductive period is prolonged and is usually associated with warmer months (Melchiors et al., 2004), specimens can be found actively calling throughout the year (DL, unpubl. data). Pseudis minuta represents a good model for testing hypotheses about responses to climate and to habitat heterogeneity because it is relatively abundant in a wide variety of aquatic habitats (Loebmann, 2005). Moreover, prior ecological studies on anuran species in this national park are scarce (Loebmann and Vieira, 2005; Moreira et al., 2010). Currently, no information is available on the ecology of $P$. minuta in this important, but poorly investigated biodiversity hotspot in South America.
Accordingly, we investigated the ecological features of a population of $P$. minuta and the relationships of this species with abiotic factors in this subtropical biosphere reserve to investigate the following two hypotheses. 1) Temporal fluctuations in the relative abundance of $P$. minuta are correlated with environmental factors. This hypothesis is suggested by the observation that some environmental conditions (e.g., temperature, rainfall) are correlated with fluctuations in the abundance of amphibian species elsewhere (Bernarde and Anjos, 1999; Conte and Machado, 2005). 2) Pseudis minuta is a habitat generalist. This hypothesis is suggested by the observation that anuran species occurring in open areas tend to show environmental plasticity, whereas most anurans inhabiting forests are adapted to live in particular microhabitats (Brasileiro et al., 2005).

\section{Material and Methods}

The field work was carried out in the "Lagoa do Peixe" National Park, a UNESCO Biosphere Reserve located on the coastal plain of the state of Rio Grande do Sul, southern Brazil (31 ${ }^{\circ} 6$ ' 50.83" S, 50 51' 20.66" W). The climate of this region is subtropical. The average annual temperature is $17.5^{\circ} \mathrm{C}$. January and February are the warmest months, and the coldest months are June and July. The rainfall ranges from 1,200 to 1,500 $\mathrm{mm}$ (Seeliger et al., 1998).

Individuals of $P$. minuta were collected in two areas of the reserve, a wetland habitat and a sand dune habitat. These areas were separated by a distance of $4.6 \mathrm{~km}$. Field studies were conducted monthly (one night per month) from April 2008 through May 2009. Sampling started at the beginning of dusk (7:00 PM) at each study site and lasted for 2.5 hours. In each area, specimens were located visually by two persons (Martins and Oliveira, 1999) in an area where vocalizations were heard. The specimens were captured by hand.

The first two field trips were devoted to a general evaluation of the different microhabitats available in the study area. We then characterized each of the microhabitats where specimens of P. minuta were found based on the following parameters: a) the spatial coverage $(\%)$ of herbaceous plants, shrubs, xerophytes and aquatic plants; b) the average height of the vegetation $(\mathrm{cm})$; c) the average water depth $(\mathrm{cm}) ; \mathrm{d})$ the substrate type (dry, wet, flooded or underwater; and e) the average distance from a water body $(\mathrm{cm})$ (Figure 1).

Simultaneously with specimen collection, these parameters were measured in a $50 \mathrm{~cm}^{2}$ area around each individual caught and were subsequently used to characterize the microhabitats (Table 1).

The activity pattern of the animals was evaluated by counting the number of $P$. minuta captured at each site during the study period. A Spearman correlation test was used to analyze the relationships between abundance and the average monthly values of air temperature, relative humidity and precipitation. This meteorological information was obtained from the Brazilian National Institute of 

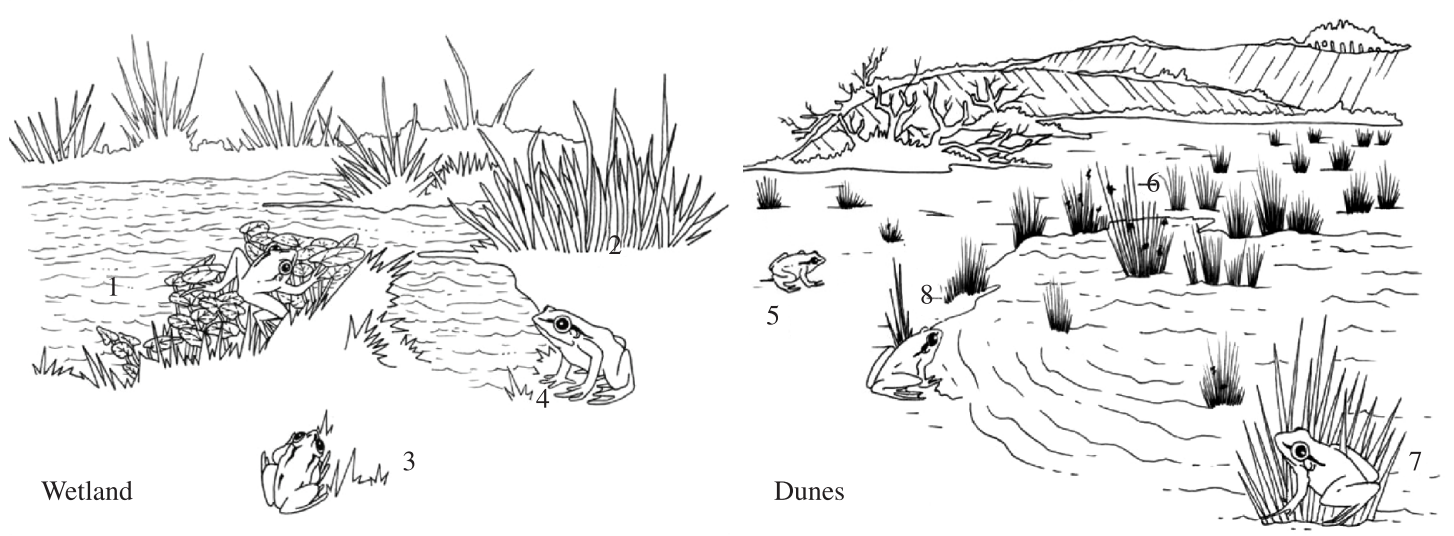

Figure 1. Schematic representation of the microhabitats in the wetland (1-4) and dunes (5-8) of the study site. See Table 1 for detailed description. Illustration by Alisson Ortiz Affonso.

Table 1. Characterization of microhabitats in the wetland (microhabitat codes 1-4) and dunes (microhabitat codes 5-8).

\begin{tabular}{|c|c|c|c|c|c|c|c|c|}
\hline \multirow{2}{*}{$\begin{array}{c}\text { Microhabitat } \\
\text { codes }\end{array}$} & \multicolumn{4}{|c|}{$\begin{array}{l}\text { Vegetation } \\
\% \text { coverage }\end{array}$} & \multirow[t]{2}{*}{ HV } & \multirow[t]{2}{*}{ WD } & \multirow[t]{2}{*}{ ST } & \multirow[t]{2}{*}{ DBW } \\
\hline & $\mathbf{A}$ & B & $\mathbf{C}$ & D & & & & \\
\hline 1 & 4 & 95 & 0 & 1 & $15-30$ & $20-50$ & flooded & $20-500$ \\
\hline 2 & 0 & 0 & 100 & 0 & 120 & 5 & dry/wet/flooded & 0 \\
\hline 3 & 5 & 95 & 0 & 0 & 20 & 0 & dry & 500 \\
\hline 4 & 0 & 100 & 0 & 0 & $15-20$ & 0 & dry/wet & 0 \\
\hline 5 & 0 & 0 & 0 & 0 & 0 & 0 & dry & $200-300$ \\
\hline 6 & 100 & 0 & 0 & 0 & $30-40$ & 0 & dry/wet & 0 \\
\hline 7 & 95 & 5 & 0 & 0 & $30-40$ & $20-40$ & flooded & $10-200$ \\
\hline 8 & 95 & 5 & 0 & 0 & $5-40$ & $1-5$ & wet/flooded & 0 \\
\hline
\end{tabular}

Abbreviations: spatial coverage (\%) of herbaceous plants (A), shrubs (B), xerophytes (C) and aquatic plants (D); average height of the vegetation (HV) $(\mathrm{cm})$; average water depth (WD) $(\mathrm{cm})$; substrate type $(\mathrm{ST})$ variation during the study (dry, wet, flooded); average distance from the microhabitat to the nearest body of water (DBW) $(\mathrm{cm})$.

Meteorology website (http://www.inmet.gov.br/). The relative frequencies of occurrence in each microhabitat were evaluated with Chi-square tests (Zar, 1994).

\section{Results}

A total of 112 juvenile and adult individuals of $P$. minuta were captured. In general, the species was active year round. However, activity fluctuated markedly during the year (Figure 2). The lowest capture rates occurred during the colder months (May through November 2008). The abundance of the animals increased during the warmer months (April 2008 and December 2008 through April 2009). The highest number of captures occurred in April $2009(n=44)$ (Figure 2).

Out of the abiotic parameters analyzed, only the average monthly values of air temperature showed a significant $(\mathrm{p}<0.05)$ and positive correlation $(\mathrm{r}=0.67)$ with the abundance of $P$. minuta. The abundance of $P$. minuta in the wetland and in the dunes was similar, and the average values of abundance did not differ significantly (Kruskal-Wallis test, $\mathrm{H}(1 ; 22)=0.187, \mathrm{p}>0.665)$.
Regardless of the location (wetland or sand dune), individuals of $P$. minuta were associated with vegetated microhabitats characterized by wet or flooded substrates. In the wetland, the observed and expected numbers of captures in microhabitat 1 did not differ significantly ( 12 observed versus 11.83 expected, $\chi^{2}=0.002, \mathrm{df}=7$, $\mathrm{p}<0.000$ ). In contrast, the number of individuals was lower than expected in microhabitat 3 ( 1 observed versus 11.83 expected, $\left.\chi^{2}=9.91, \mathrm{df}=7, \mathrm{p}<0.000\right)$ and in microhabitat 4 ( 3 observed versus 11.83 expected, $\chi^{2}=6.59$, df $=7$, $\mathrm{p}<0.000$ ). No individuals were caught in microhabitat 2 ( 0 observed, 11.83 expected, $\chi^{2}=11.83, \mathrm{df}=7, \mathrm{p}<0.000$ ).

In the dunes, the number of individuals was higher than expected in microhabitat 7 (31 observed vs. 11.83 expected, $\left.\chi^{2}=31, \mathrm{df}=7, \mathrm{p}<0.000\right)$ and in microhabitat 8 ( 22 observed versus 11.83 expected, $\chi^{2}=8.74, \mathrm{df}=7$, $\mathrm{p}<0.000)$ and lower than expected in microhabitat 5 (2 observed versus 11.83 expected, $\chi^{2}=8.16, \mathrm{df}=7, \mathrm{p}<0.000$ ). No individuals were found in microhabitat $6(0$ observed vs. 11.83 expected, $\chi^{2}=11.83, \mathrm{df}=7, \mathrm{p}<0.000$ ). 

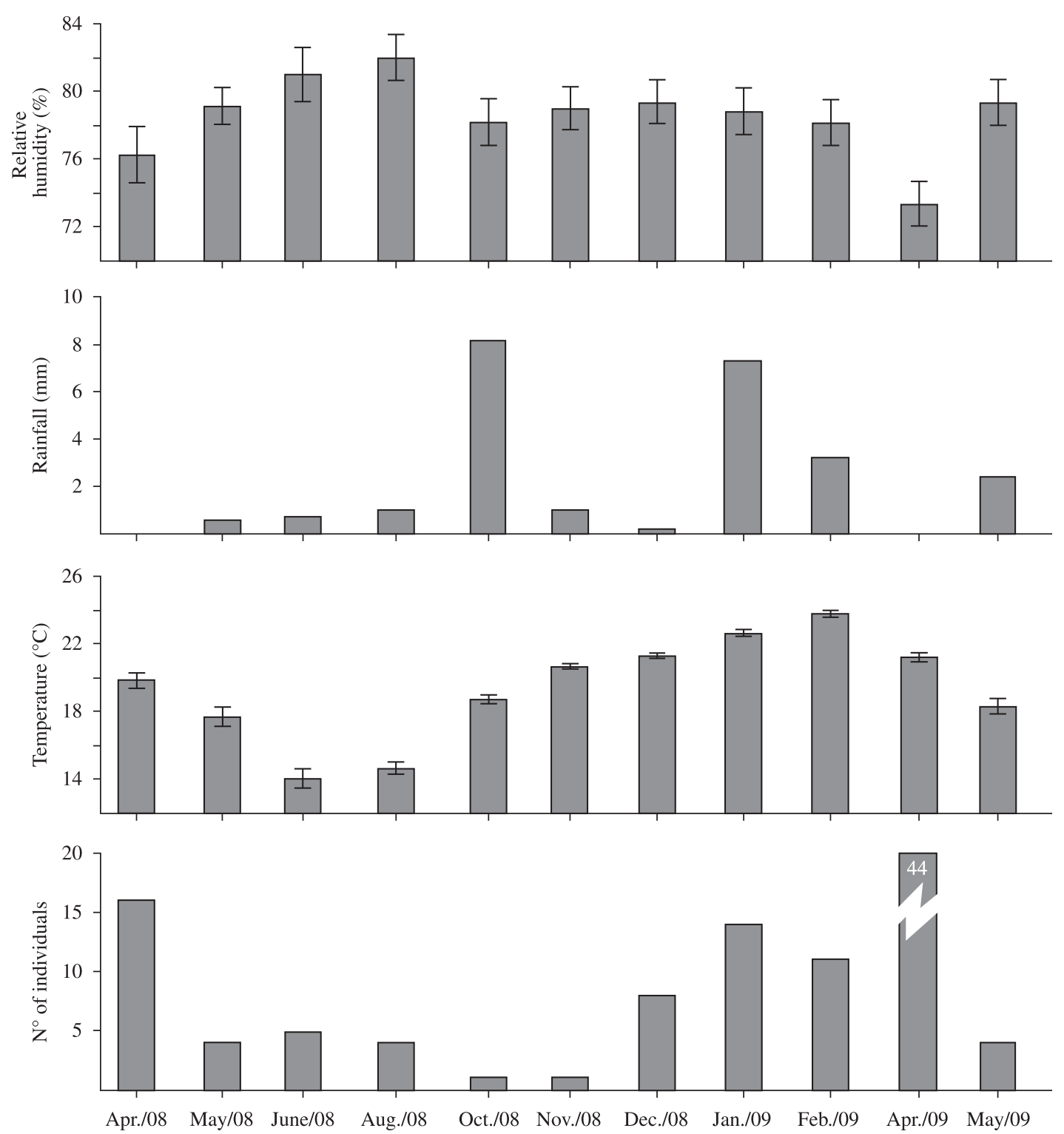

Figure 2. Temporal variation in the total number of individuals of P. minuta captured per month and per monthly average values of relative humidity $(\%)$, rainfall $(\mathrm{mm})$ and air temperature $\left({ }^{\circ} \mathrm{C}\right)$ at the study site (wetland and dune habitats pooled).

\section{Discussion}

Present results indicate that $P$. minuta was more abundant during the warmer conditions occurring during the austral spring, summer and early autumn. The abundance of the species was also positively correlated with the air temperature. Previous studies of $P$. minuta in regions of the subtropical zone located farther inland have indicated similar positive relationships between abundance or activity patterns and temperature (Santos et al., 2008). Likewise, Zank et al. (2010) found that reproductive activity in $P$. minuta is influenced by temperature and rainfall but not by other climatic factors. In a broader context, it has been argued that in tropical latitudes the reproductive activity of amphibians is influenced primarily by rainfall (Aichinger, 1987), whereas in temperate regions, both rainfall and temperature seem to play a major role in amphibians' reproductive behavior (Zank et al., 2010). Hence, our findings for a subtropical region seem to agree with the results from temperate latitudes.

At a microhabitat scale, most individuals of $P$. minuta observed in the present study were associated with aquatic environments, especially those in which vegetation occurred. Prior studies on congeneric species also showed a strong association of this taxon with aquatic habitats and seem consistent with our current findings. For example, Pseudis cardosoi Kwet, 2000 is also found in aquatic habitats, although it can occur in terrestrial habitats 
located close to the Araucaria forest (Miranda et al., 2006). Similarly, Duré and Kehr (2001) have shown that Lysapsus limellum Cope, 1862, a sister genus of Pseudis, and Pseudis paradoxa (Linnaeus, 1758) inhabit aquatic habitats and forage mainly on top of the floating vegetation of permanent lakes.

Although the morphology of Pseudis minuta would seem to suggest a preference for aquatic environments (this species has well-developed interdigital membranes on the hind feet and the eyes are positioned dorso-laterally), the preference of species for flooded areas may also be related to a phylogenetic tendency shown by the group. The tribe Dendropsophini (sensu Faivovich et al., 2005) currently includes 224 valid species in seven genera. Dendropsophus (92), Scarthyla (2), Scinax (102), and Xenohyla (2) are exclusively arboreal. These genera include ca. $90 \%$ of the species belonging to this tribe. Sphaenorhyncus (14) has been considered an arboreal genus, but it occupies an intermediate position on an aquatic-arboreal continuum. The species in this group are all associated with bromeliads or ponds with associated vegetation. However, all Pseudis (9) and Lysapsus (3) species are exclusively aquatic. Therefore, the evolutionary history of this genus suggests a radiation of the tribe from arboreal to aquatic life.

In the current study, the abundance of $P$. minuta did not show a significant correlation with most of the measured physical factors (except temperature). This finding could imply that the species has relatively broad environmental requirements. Moreover, the species was found both in wetland and dune areas, where it was associated with permanent and temporary aquatic habitats. This pattern supports the hypothesis that $P$. minuta is a generalist species in its use of habitat and environmental resources (Santos et al., 2008). In fact, this species has been reported to occur in urban areas of densely populated cities (Rodrigues et al., 2008).

Our findings seemed to support the two hypotheses outlined in this work. First, the abundance of $P$. minuta in the subtropical latitudes of southern Brazil can be influenced by climatic factors such as air temperature. Second, the species shows highly plastic patterns of habitat and microhabitat utilization.

Acknowledgements - We would like to thank all of our colleagues who helped with data collection and with suggestions on the manuscript. We would also like to thank Maria Tereza Queiroz Melo for her support and assistance in the Park, the ICMBIO for providing permits (14523-2 and 14523-4) for sample collections and the International Foundation for Science (grant $\mathrm{n}^{\circ}$. A/4419-1), CNPq (grant $\mathrm{n}^{\circ}$. 482920/2007-6) and CAPES (graduate scholarship to $\mathrm{SH}$ ) for providing research funds.

\section{References}

ACHAVAL, F. and OLMOS A., 2003. Anfíbios e Reptiles Del Uruguay. 2nd ed. Montevideo: Graphis Impresora. 136 p.

AICHINGER, M., 1987. Annual activity patterns of anurans in a seasonal Neotropical environment. Oecologia, vol. 71, p. 583592. http://dx.doi.org/10.1007/BF00379302
BERNARDE, PS. and ANJOS, L., 1999. Distribuição espacial e temporal as anurofauna no Parque Estadual Mata dos Godoy, Londrina, Paraná, Brasil (Amphibia: Anura). Comunicações do Museu Ciência Tecnologia PUCRS, Série zoologia, vol. 12, p. $127-140$.

BRANDÃO, RA., GARDA, A., BRAZ, V. and FONSECA, B., 2003. Observations on the ecology of Pseudis bolbodactyla (Anura: Pseudidae) in central Brazil. Phyllomedusa, vol. 2, no.1, p. 3-8.

BRASILEIRO, CA., SAWAYA, RJ., KIEFER, MC. and MARTINS, M., 2005. Amphibians of na open Cerrado fragment in Southeastern Brazil. Biota Neotropica, vol. 5, no. 2, p. 1-17.

CONTE, CE. and MACHADO, RA., 2005. Riqueza de espécies e distribuição espacial e temporal em comunidade de anuros (Amphibia, Anura) em uma localidade de Tijucas do Sul, Paraná, Brasil. Revista Brasileira de Zoologia, vol. 22, no. 4, p. 940-949.

CONTE, CE. and ROSSA-FERES, C., 2007. Riqueza e distribuição espaço-temporal de anuros em um remanescente de Floresta de Araucária no sudeste do Paraná. Revista Brasileira de Zoologia, vol. 24, no. 4, p. 1025-1037.

DUELLMAN, WE., 1995. Temporal fluctuations in abundance of anuran amphibians seasonal Amazonian Rainforest. Journal of Herpetology, vol. 29, no. 1, p. 13-21. http://dx.doi. org/10.2307/1565080

DUELLMAN, WE. and TRUEB, L., 1994. Biology of Amphibians. Maryland: The Johns Hopkins University Press. 670 p.

DURÉ, MI. and KEHR, AI., 2001. Differential Exploitation of Trophic Resources by two Pseudid Frogs from Corrientes, Argentina. Journal of Herpetology, vol. 35, no. 2, p. 340- 343. http://dx.doi.org/10.2307/1566129

LOEBMANN, D., 2005. Guia Ilustrado: Os anfíbios da região costeira do extremo sul do Brasil. Pelotas: USEB. 76 p.

LOEBMANN, D. and VIEIRA, JP., 2005. Relação dos anfíbios do Parque Nacional da Lagoa do Peixe, RS, Brasil. Revista Brasileira de Zoologia, vol. 22, no. 2, p. 339-341. http://dx.doi. org/10.1590/S0101-81752005000200006

MARTINS, M. and OLIVEIRA, ME., 1999. Natural history of snakes in forest of the Manaus region, Central Amazonia, Brazil. Herpetological Natural History, vol. 6, p. 78-150.

MELCHIORS, J., DI BERNARDO, M., PONTES, G., OLIVEIRA, R., SOLE, M. and KWET, A., 2004. Reprodução de Pseudis minuta (Anura, Hylidae) no sul do Brasil. Phyllomedusa, vol. 3, no. 1 , p. 61-68.

MIRANDA, T., EBNER, M., SOLÉ, M. and KWET, A., 2006. Spatial, seasonal and intrapopulational variation in the diet of Pseudis cardosoi (Anura: Hylidae) from the Araucaria Plateau of Rio Grande do Sul, Brazil. South American Journal of Herpetology, vol. 1, no. 2, p. 121-130. http://dx.doi.org/10.2994/18089798(2006)1[121:SSAIVI]2.0.CO;2

MOREIRA, LFB., MACHADO, IF., GARCIA, TV. and MALTCHIK, L., 2010. Factors influencing anuran distribution in coastal dune wetlands in southern Brazil. Journal of Natural History, vol. 1, no. 1, p. 1493-1507.

RODRIGUES, RG., MACHADO, IF. and CHRISTOFF, AU., 2008. Anurofauna em área antropizada no campus ULBRA, Canoas Rio Grande do Sul, Brasil. Biodiversidade Pampeana, vol. 6 , no. 2, p. 39-43.

SANTOS, TG., KOPP, K., SPIES, MR., TREVISAN, R. and CECHIN, SZ., 2008. Distribuição temporal e espacial de anuros 
em área de Pampa, Santa Maria, RS. Iheringia. Série Zoologia, vol. 98 , no. 2, p. 244-253.

SCHINEIDER, JA. and TEIXEIRA, RL., 2001. Relacionamento entre anfíbios anuros e bromélias da restinga de Regência, Linhares, Espírito Santo, Brasil. Iheringia. Série Zoologia, vol. 91, p. 41-48.

SEELIGER, U., ODEBRECHT, C. and CASTELLO, JP., 1998. Os ecossistemas costeiro e marinho do extremo sul do Brasil, Rio Grande (RS). Rio Grande: Editora Ecoscientia. 341 p.

TOZETTI, AM. and TOLEDO, LF., 2005. Short-term movement and retreat sites of Leptodactylus labyrinthicus (Anura: Leptodactylidae) during the breeding season: a spool-and-line tracking study. Journal of Herpetology, vol. 39, no. 4, p. 640-644. http://dx.doi. org/10.1670/155-04N.1

VASCONCELOS, TS. and ROSSA-FERES, DC., 2005. Diversidade, distribuição espacial e temporal de anfíbios anuros (Amphibia,
Anura) na região noroeste do estado de São Paulo, Brasil. Biota Neotropica, vol. 5, no. 2, p. 1-14.

-, 2008. Habitat heterogeneity and use of physical and acoustic space in anuran communities in Southeastern Brazil. Phyllomedusa, vol. 7, no. 2, p. 127-142.

WIEST JUNIOR, JA., 1982. Anuran succession at temporary ponds in a post oak savanna region of Texas. In SCOTT JUNIOR, NJ. (Eds.). Herpetological Communites. Washington: USDI Fish and Wildlife Service. p. 39-47.

ZANK, C., DI-BERNARDO, M., MANEYRO, R., COLOMBO, P., FUSINATTO, LA. and FONTE, LFM., 2010. Spatial and temporal distribution of Pseudis minuta Günther, 1858 (Anura, Hylidae, Hylinae) and environmental variables related with its reproductive activity in Reserva Biológica do Lami (Porto Alegre, Brazil). Iheringia. Série Zoologia, vol. 100, no. 2, p. 145-150.

ZAR, JH., 1994. Biostatistical analysis. 2nd ed. Upper Saddle River: Prentice Hall. 929 p. 